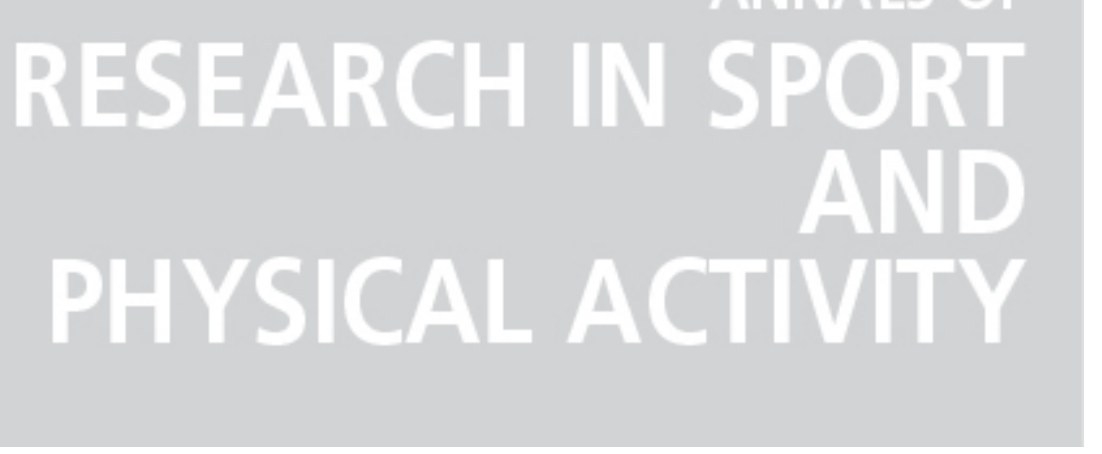

\title{
Fat oxidation in ageing: effect of exercise training
}

Autor(es): $\quad$ Palumbo, A. Scotto di; Sacchetti, M.

Publicado por: Imprensa da Universidade de Coimbra

URL

persistente:

DOI:

URI:http://hdl.handle.net/10316.2/3374

DOI:http://dx.doi.org/10.14195/2182-7087_2_10

Accessed : $\quad$ 26-Apr-2023 15:09:03

A navegação consulta e descarregamento dos títulos inseridos nas Bibliotecas Digitais UC Digitalis, UC Pombalina e UC Impactum, pressupõem a aceitação plena e sem reservas dos Termos e Condições de Uso destas Bibliotecas Digitais, disponíveis em https://digitalis.uc.pt/pt-pt/termos.

Conforme exposto nos referidos Termos e Condições de Uso, o descarregamento de títulos de acesso restrito requer uma licença válida de autorização devendo o utilizador aceder ao(s) documento(s) a partir de um endereço de IP da instituição detentora da supramencionada licença.

Ao utilizador é apenas permitido o descarregamento para uso pessoal, pelo que o emprego do(s) título(s) descarregado(s) para outro fim, designadamente comercial, carece de autorização do respetivo autor ou editor da obra.

Na medida em que todas as obras da UC Digitalis se encontram protegidas pelo Código do Direito de Autor e Direitos Conexos e demais legislação aplicável, toda a cópia, parcial ou total, deste documento, nos casos em que é legalmente admitida, deverá conter ou fazer-se acompanhar por este aviso. 
(2) 2011

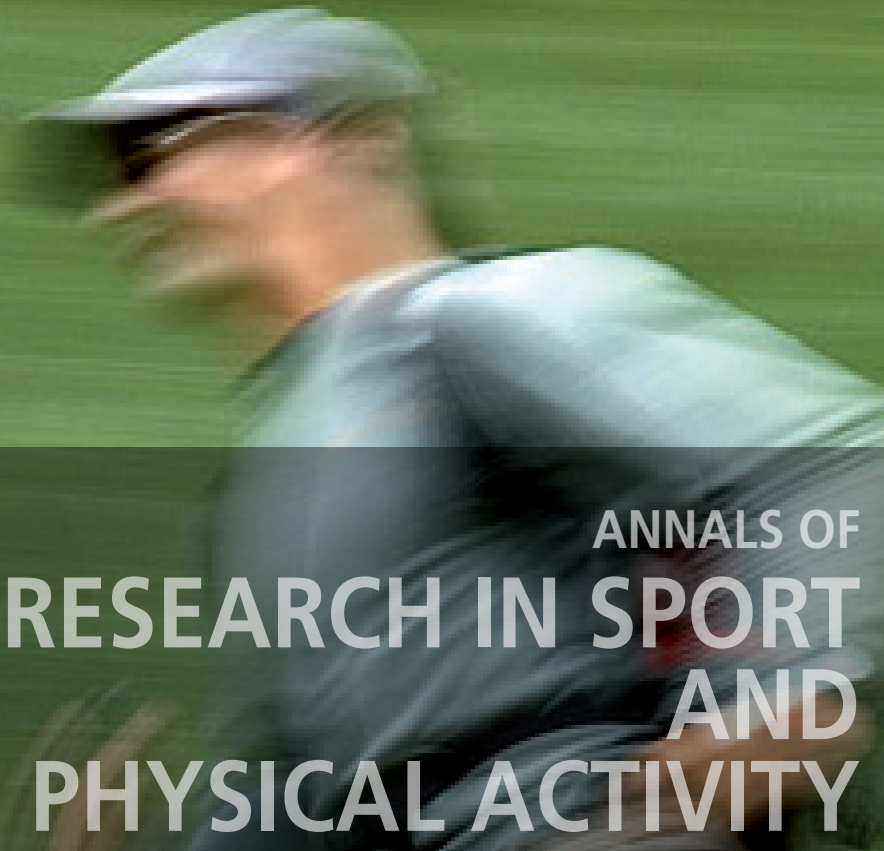

FACULDADE DE

CIÊNCIAS DO

DESPORTO E

EDUCAÇÃO FÍSICA DA UNIVERSIDADE DE COIMBRA

IMPRENSA

DA UNIVERISDADE

DE COIMBRA 
2・SPORT TRAINING

FAT OXIDATION IN AGEING: EFFECT OF EXERCISE TRAINING 


\section{A. Scotto di Palumbo', M. Sacchetti}

\section{INTRODUCTION}

Ageing is associated with deleterious changes of energy metabolism, whereas exercise training has the potential to counteract this phenomenon. The aim of the present study was to investigate the effect of ageing, endurance training and their interaction on the oxidative capacity during exercise.

\section{METHODS}

Eight elderly master cyclists (ET) and eight age-matched sedentary controls (EU), ten young elite cyclists (YT) and nine age-matched sedentary controls (YU) underwent an incremental cycling test $\left(35 \%, 45 \%, 55 \%, 65 \%, 75 \%\right.$, and $85 \%$ of $\mathrm{VO}_{2}$ max previously determined) to assess maximal lipid oxidation capacity (fat max), measured by indirect calorimetry.

\section{RESULTS}

YT showed the highest maximal fat oxidation $\left(0.85 \pm 0.14 \mathrm{~g}^{\star} \mathrm{min}^{-1}\right)$, which was occurring between $65 \%$ and $75 \%$ of $\mathrm{VO}_{2}$ max. Differently, fat max was lower $\left(0.26 \pm 0.8 \mathrm{~g}^{\star} \mathrm{min}^{-1}\right)$ and peaked quite early in EU. ET showed a relatively high fat oxidation capacity $(0.49 \pm 0.12$ $\left.\mathrm{g}^{*} \mathrm{~min}^{-1}\right)$, which was superior and was peaking at higher intensities than in $\mathrm{YU}$, who, on the other hand, had a comparable $\mathrm{VO}_{2}$ max.

\section{DISCUSSION}

The analysis of the contribution to total energy expenditure (CTEE) revealed that the intensity at which fat CTEE was equivalent to CHO. CTEE was shifted towards higher values in the trained groups. Such results indicate that chronic endurance training contrast the decay in oxidative capacity, in particular lipid oxidation capacity during exercise.

\footnotetext{
1 University of Rome "Foro Italico", Italy; e-mail: a.scottodipalumbo@hotmail.it.
} 